Original Article

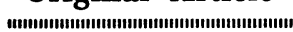

\title{
Residue Analysis of Oleic Acid in Cucumber Fruits after Spraying Sodium Oleate Solution
}

\author{
Masanobu Fujir, Akira Tokumura,* Toshihiko Tsutsumi,* \\ Hiroaki Tsukatani,* Mikio KAno** and Akira TANAKA** \\ School of Medical Sciences, The University of Tokushima, \\ Kuramoto-cho, Tokushima 770, Japan \\ *Faculty of Pharmaceutical Sciences, The University of Tokushima, \\ Sho-machi, Tokushima 770, Japan \\ **Otsuka Chemical Co., Ltd., Agrochemicals Research and Development Department, \\ Chuo-ku, Osaka 540, Japan
}

(Received July 16, 1991; Accepted April 16, 1992)

\begin{abstract}
Residue of cis-9-octadecenoic acid (ODA) was studied by gas chromatographic analysis of cucumber fruit sprayed with sodium oleate $(20 \%$ liquid formulation), an aphicide under development at present in our laboratory. Endogenous ODA was 0.33 and $0.37 \mathrm{ppm}$ in two cultivars of cucumber fruit. Residue levels on the first day after last spraying were 1.81 and $3.57 \mathrm{ppm}$, and on the third day they lowered to 0.88 and $1.01 \mathrm{ppm}$. Recovery of ODA from untreated cucumber fruit to which $2.5 \mathrm{ppm}$ ODA had been added was in a range of 102.0 to $108.4 \%$.
\end{abstract}

\section{INTRODUCTION}

Extensive investigations have been done to reassess standard levels of pesticide residue in food, with an increased social concerns for safety of imported foods and toxicity of pesticide residues. ${ }^{1)}$

We have been developing a new low-toxicity aphicide using sodium oleate as an active ingredient, ${ }^{2,3)}$ which has been approved as a food additive ${ }^{4)}$ with low-toxicity even if it remains in food.

The present study was aimed to study residue levels of cis-9-octadecenoic acid (ODA) after spraying it on cucumber fruit in a liquid form.

\section{MATERIALS AND METHODS}

\section{Crop Preparations}

\subsection{Liquid for spraying}

Sodium oleate liquid contained $20 \%$ sodium cis-9-octadecenate as an active ingredient.

\subsection{Crops}

Two kinds of cucumber fruit (A: Cucumis sativus cv. Sharp 1) and (B: Cucumis sativus cv. Hokuho No. 2) were from the Gunma Agricultural Research Center (Togo-cho, Tatebayashi-city, Gunma prefecture) and the Research Institute of Japan Plant Protection Association (Kessoku-cho, Ushiku-city, Ibaraki prefecture), respectively. On harvest time, thirtyfold diluted solution of sodium oleate liquid was sprayed five times to cucumber fruits $\mathrm{A}$ and $\mathrm{B}$, being cultivated in a green house.

Cucumbers were harvested on the first day (T-1) and third day (T-3) after last spraying.

The five times spraying on cucumber A (200$250 l / 10 \mathrm{a})$ were performed on the eleventh, eighth, fourth and first day before T-1.

The five times spraying on cucumber $B$ (150-240 l/10 a) were done on the thirteenth, tenth, seventh, fourth and first day before T-1.

\section{Analytical Methods}

\subsection{Reagents}

Cis-9-octadecenoic acid (ODA: oleic acid, $\mathrm{C}_{18: 1}$ over $99 \%$ purity) was from Sigma Chemi- 
cal Co., and heptadecanoic acid $\left(\mathrm{C}_{17: 0}\right.$ over $98 \%$ purity) and 2-p-toluidinylnaphthalene-6-sulfonic acid (TNS reagent) were from Aldrich Chemical Co.

Palmitic acid $\left(\mathrm{C}_{16: 0}\right)$, stearic acid $\left(\mathrm{C}_{18: 0}\right)$, linoleic acid $\left(\mathrm{C}_{18: 2}\right)$, linolenic acid $\left(\mathrm{C}_{18: 3}\right)$ and $N$-methyl- $N$-nitroso- $p$-toluene sulfonamide were from Wako Pure Chemical Ind.

Silica gel 60 plates for TLC $(20 \times 20 \mathrm{~cm}, 0.25$ $\mathrm{mm}$ thickness) were from Merck.

The organic solvents used in this study were all special grade from Wako Pure Chemical Ind.

\subsection{Conditions for gas chromatography (GC)}

GC was carried out on a Hitachi 263-70 equipped with a fused silica capillary column ( $\mathrm{J} \& \mathrm{~W}, \mathrm{DB}-225,30 \mathrm{~m} \times 0.25 \mathrm{~mm}$ ) and a Hydrogen Flame Ionization Detector (FID).

Column temperature was programmed to increase from $180^{\circ} \mathrm{C}$ to $220^{\circ} \mathrm{C}$ at a rate of $4^{\circ} \mathrm{C} /$ min. Temperatures of the detector and injection port were maintained at $250^{\circ} \mathrm{C}$. Gas flow rates were adjusted to $50 \mathrm{ml} / \mathrm{min}$ (carrier gas, $\mathrm{He}), \quad 1.2 \mathrm{~kg} / \mathrm{cm}^{2}\left(\mathrm{H}_{2}\right)$ and $0.75 \mathrm{~kg} / \mathrm{cm}^{2}$ (air).

Other conditions: sensitivity, attenuation $2 \mathrm{~V}$ and range $10^{2} \Omega$; mode of injection, without solvent and chart speed, $10 \mathrm{~mm} / \mathrm{min}$.

\subsection{Calibration curve}

ODA $250 \mathrm{mg}$ was dissolved in $25 \mathrm{ml}$ chloroform. Heptadecanoic acid $250 \mathrm{mg}$ as an internal standard for GC was prepared in $25 \mathrm{ml}$ chloroform. ODA solution in a range of 2 to $60 \mu 1$ was mixed with $20 \mu 1$ heptadecanoic acid solution and the mixture was evaporated to dryness under reduced pressure.

To the residue was added diazomethane solution in ethyl ether.

The reaction mixture was allowed to stand at room temperature for $10 \mathrm{~min}$, and ethyl ether was evaporated under a stream of nitrogen. The methylated sample was dissolved in $1 \mathrm{ml} n$-hexane, and a 2 - $\mu \mathrm{l}$ aliquots of the solution was injected into GC.

Calibration curve was made by plotting weight ratios of ODA to those of heptadecanoic acid against area ratios of ODA to heptadecanoic acid.

\subsection{Analytical procedures}

(1) Extraction of lipids from cucumber fruit Frozen cucumber fruit (about $100 \mathrm{~g}$ ) was homogenized with $150 \mathrm{ml}$ mixture of chloroform/methanol $(1 / 2, \mathrm{v} / \mathrm{v}: \mathrm{CM})$ containing 500 $\mu \mathrm{g}$ heptadecanoic acid with a speed cutter for 2 min at $-10^{\circ} \mathrm{C}$.

Under reduced pressure the homogenate was filtered through a Celite layer on Toyo No. 2 filter paper. The residue was washed with a mixture of $150 \mathrm{ml} \mathrm{CM}$ and $40 \mathrm{ml}$ distilled water, and then with $75 \mathrm{ml} \mathrm{CM}$ solution. ${ }^{5}$ ) The combined $\mathrm{CM}$ extract was underwent a procedure to remove non-lipids.

(2) Removal of non-lipids

The CM extract was transferred to a separatory funnel, and mixed with $125 \mathrm{ml}$ distilled water containing $10 \mathrm{~g}$ pottasium chloride and $125 \mathrm{ml}$ chloroform. The mixture was shaken for $10 \mathrm{~min}$. After phase separation, an upper layer containing non-lipids was transferred into a flask, to which $250 \mathrm{ml}$ chloroform was added. The mixture was vigorously shaken, and the chloroform layers were combined and evaporated to dryness under reduced pressure at $35^{\circ} \mathrm{C} .{ }^{5)}$

(3) Purification of free fatty acids by TLC

The residue obtained in experiment (2) was dissolved in $10 \mathrm{ml} \mathrm{CM}$ with an aid of a sonicater. An aliquot $(100 \mu \mathrm{l})$ of the solution was applied as a line on a TLC plate preactivated at $110^{\circ} \mathrm{C}$ for $1 \mathrm{hr}$ after being washed with methanol.

The plate was developed with a solvent system of petroleum ether/ethyl ether/acetic acid $(74 / 15 / 1, \mathrm{v} / \mathrm{v} / \mathrm{v})$. Lipids were visualized under a UV lamp after spraying with the TNS reagent. Free fatty acids were detected as a blue-white line ( $R f$ value: 0.33). Silica gel containing fatty acids was scraped off the plate and transferred to a conical bottom tube. CM $(7.5 \mathrm{ml})$ and distilled water $(2 \mathrm{ml})$ were added to the silica gel, and the mixture was adjusted to $\mathrm{pH} 3.0$ with $1 \mathrm{~N}$-hydrochloric acid. After addition of $2.5 \mathrm{ml}$ distilled water and $2.5 \mathrm{ml}$ chloroform, the mixture was centrifuged at $2000 \times g$ for $10 \mathrm{~min}$. The chloroform layer was withdrawn with a Pasteur pipet. ${ }^{6)}$ To the remaining aqueous layer was added $5 \mathrm{ml}$ chloroform, and the mixture was centrifuged at $2000 \times g$ for $10 \mathrm{~min}$. The combined chloroform extract was evaporated to dryness under reduced pressure. The residue was treated with diazomethane solution in ethyl ether at 
room temperature for $10 \mathrm{~min}$ to obtain methyl esters of fatty acids.

(4) Determination of methyl esters of fatty acids by GC

The methyl esters of fatty acids obtained in experiment (3) were dissolved in $0.1 \mathrm{ml} n$ hexane, and a $2-\mu \mathrm{l}$ aliquot of the solution was injected into GC under the condition as described in 2.2 .

Ratios of the peak area of ODA to that of heptadecanoic acid in gaschromatogram were calculated. Weight ratios of ODA to heptadecanoic acid (B) were obtained from the ratios of the peak area with an aid of calibration curve. Concentrations of ODA in samples were calculated by the following equation.

Concentration of ODA in cucumber fruit (ppm) $=(A \times B) /$ weight of cucumber fruit $(\mathrm{g})$

$A$ : weight $(\mu \mathrm{g})$ of internal standard (IS)

$B$ : weight ratio of ODA to heptadecanoic acid as IS.

\section{RESULTS AND DISCUSSION}

\section{Residue of ODA after Spraying Sodium} Oleate Liquid on Cucumber Fruit

Table 1 shows the amount of ODA in cucumber fruit at T-1 and T-3. Values were corrected by subtracting the amount of endogenous ODA in untreated cucumber. Figure 1 shows a typical chromatogram of fatty acid methyl esters from untreated cucumber.

Both cucumber fruit $\mathrm{A}$ and $\mathrm{B}$ contained five free fatty acids: palmitic acid $\left(\mathrm{C}_{16: 0}\right)$, stearic acid $\left(\mathrm{C}_{18: 0}\right)$, oleic acid (ODA, $\left.\mathrm{C}_{18: 1}\right)$, linoleic

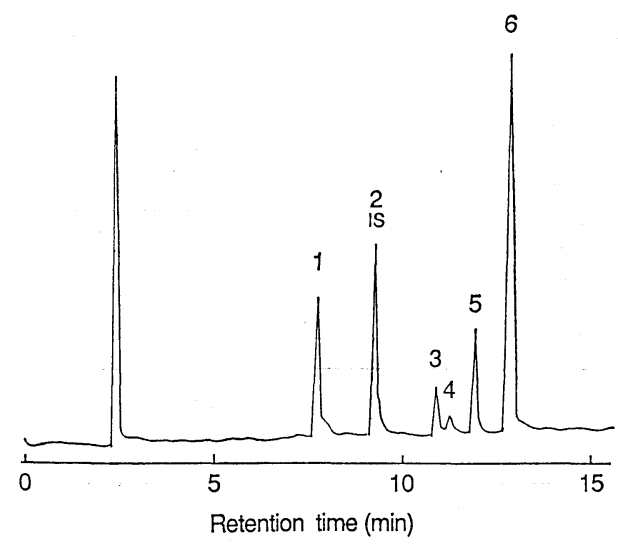

Fig. 1 Gas chromatogram of the methyl esters of free fatty acids in untreated cucumber fruit.

1: Palmitic acid $\left(\mathrm{C}_{16: 0}\right), 2$ : Heptadecanoic acid $\left(\mathrm{C}_{17: 0}\right)$ IS (Internal Standard), 3: Stearic acid $\left(\mathrm{C}_{18: 0}\right)$, 4: cis-9-octadecenoic acid (ODA) $\left(\mathrm{C}_{18: 1}\right)$, 5: Linoleic acid $\left(\mathrm{C}_{18: 2}\right)$, 6: Linolenic acid $\left(\mathrm{C}_{18: 3}\right)$.

acid $\left(\mathrm{C}_{18: 2}\right)$ and linolenic acid $\left(\mathrm{C}_{18: 3}\right)$, consistent with previous reports. ${ }^{7,8)}$

Endogenous ODA was comprised at most $1.8 \%$ of free fatty acids (Table 2). There have been a few studies measuring free fatty acids in cucumber fruit. Kinsella ${ }^{8)}$ has reported that neutral lipids were about $39 \%$ of the total lipids, about $0.1 \mathrm{~g}$ per $100 \mathrm{~g}$ cucumber fruit, and that about $4.3 \%$ of the neutral lipids were free fatty acids (about $17 \mathrm{ppm}$ as fatty acids in cucumber fruit). Since the area $\%$ of ODA obtained in our experiment was about $1.8 \%$ of the total fatty acids, the

Table 1 ODA residues in cucumber fruit.

\begin{tabular}{|c|c|c|c|c|}
\hline & \multicolumn{2}{|c|}{ Cucumber A } & \multicolumn{2}{|c|}{ Cucumber B } \\
\hline & $\begin{array}{c}\text { Found }{ }^{\mathrm{A})} \\
(\mathrm{ppm})\end{array}$ & $\begin{array}{l}\left.\text { Corrected }^{a}\right) \\
\text { found } \\
\text { (ppm) }\end{array}$ & $\begin{array}{l}\left.\text { Found }{ }^{\mathrm{B}}\right) \\
(\mathrm{ppm})\end{array}$ & $\begin{array}{l}\left.\text { Corrected }{ }^{b}\right) \\
\text { found } \\
(\mathrm{ppm})\end{array}$ \\
\hline Untreated & $0.33 \pm 0.12$ & & $0.37 \pm 0.05$ & \\
\hline$T-1^{c)}$ & $2.14 \pm 0.25$ & $1.81 \pm 0.25$ & $3.94 \pm 1.00$ & $3.57 \pm 1.00$ \\
\hline$\left.T-3^{d}\right)$ & $1.21 \pm 0.12$ & $0.88 \pm 0.12$ & $1.38 \pm 0.38$ & $1.01 \pm 0.38$ \\
\hline
\end{tabular}

Values represent means \pm S.D. of four samples.

a) Values were obtained by subtracting 0.33 from $\mathrm{A}$ ).

b) Values were obtained by subtracting 0.37 from B).

c) Residues of ODA in cucumber fruit on the first day after last spraying of sodium oleate liquid.

d) Residues of ODA in cucumber fruit on the third day after last spraying of sodium oleate liquid. 
Table 2 Free fatty acids in untreated cucumber fruit.

\begin{tabular}{ccccc}
\hline \multicolumn{5}{c}{ Free fatty acids (\%) } \\
\hline $\mathrm{C}_{18: 0}$ & $\mathrm{C}_{18: 0}$ & $\mathrm{C}_{18: 1}$ & $\mathrm{C}_{18: 2}$ & $\mathrm{C}_{18: 3}$ \\
\hline $17.5 \pm 5.3$ & $6.9 \pm 2.1$ & $1.8 \pm 0.4$ & $14.4 \pm 3.4$ & $59.5 \pm 4.2$ \\
\hline
\end{tabular}

Values represent means \pm S.D. of four samples as $\%$ of the total free fatty acids.

Table 3 Recoveries of ODA added to untreated cucumber fruit.

\begin{tabular}{llllll}
\hline & $\begin{array}{l}\text { Added } \\
(\mathrm{ppm})\end{array}$ & $\begin{array}{l}\text { Found } \\
(\mathrm{ppm})\end{array}$ & CV $^{\mathrm{b})}$ & $\begin{array}{c}\text { Corrected } \\
\text { found } \\
(\mathrm{ppm})\end{array}$ & $\begin{array}{c}\text { Recovery } \\
(\%)\end{array}$ \\
\hline Cucumber A & 2.5 & $2.88 \pm 0.06$ & 2.1 & $2.55 \pm 0.11$ & 102.0 \\
Cucumber B & 2.5 & $3.09 \pm 0.19$ & 5.8 & $2.71 \pm 0.17$ & 108.4 \\
\hline
\end{tabular}

Values represent means \pm S.D. of four samples.

b) Coefficient variation of a).

c) Values were obtained by the method described in Table 1.

amount of ODA was estimated to be about $0.31 \mathrm{ppm}$ in the cucumber fruit, based on Kinsella's result, which is close to 0.33 and $0.37 \mathrm{ppm}$ obtained in the present study on endogenous ODA in cucumber $\mathrm{A}$ and $\mathrm{B}$, respectively.

As shown in Table 1, residue levels of ODA at $\mathrm{T}-1$ in cucumber $\mathrm{A}$ and $\mathrm{B}$ were $1.81 \pm 0.25$ and $3.57 \pm 1.00 \mathrm{ppm}$, respectively. The residue level in cucumber $B$ was higher than that in cucumber A. Residues of ODA in cucumber $\mathrm{A}$ and $\mathrm{B}$ lowered to 0.88 and $1.01 \mathrm{ppm}$, respectively at T-3. The values were not significantly different. These results show ODA decreased about 50 to $70 \%$ within 2 days. Our preliminary experiments show that almost all ODA sprayed in sodium oleate liquid to cucumber fruit could be easily removed by washing with water by hands (Unpublished data by M. Fujii \& A. Tokumura).

\section{Test for Recovery}

ODA was added to frozen cucumber fruit (about $100 \mathrm{~g}$ ) and the recovery was determined by GC after extraction of lipids followed by purification of free fatty acids by TLC and their methylation, as described in the analytical procedures.

Recovery was calculated from the values corrected by subtracting the amount of endogenous ODA (cucumber A: 0.33 , and cucum- ber B: $0.37 \mathrm{ppm})$. Table 3 shows excellent recovery of ODA from both cucumber A $(102.0 \%)$ and $B(108.4 \%)$.

Endogenous ODA in the cucumber fruit was relatively low, compared with other fatty acids such as palmitic acid, stearic acid, linoleic acid and linolenic acid, affecting to a lesser extent on the residue after spraying. In addition, ODA is much less susceptible to lipoxygenase during the process of griding than polyunsaturated fatty acids. ${ }^{7,9,10)}$ These are benefits of ODA.

The result that residual ODA was small in amount shows that ODA is low in toxicity when used both as an additive to daily food and as an aphicide.

\section{REFERENCES}

1) Health and Welfare Statistics Association: Kokumin Eisei no Doko (Health and Welfare Index, extra edition), 37 (9), p. 294, 1990

2) Japan Plant Protection Association: The records of a general entrusted experiment (II, Tohoku region, Iwate Plant Protection Association). The reports on pesticide, p. 3, 1990

3) Japan Plant Protection Association: The records of a general entrusted experiment (V, Kinki, Chugoku region, Kyoto Prefectural Research Institute of Agriculture). The reports on pesticide, p. 5, 1990

4) Japan Food Additives Association: Japanese Standards of Food Additives-V, p. 177, 1986 
5) M. Kates: Adv. Lipid Res. 8, 225 (1970)

6) E. G. Bligh \& W. Dyer: Can. J. Biochem. Physiol. 37, 911 (1959)

7) H. S. Geduspan \& A. C. Peng: J. Food Sci. 51, 852 (1986)

8) J. E. Kinsella: J. Food Sci. 36, 865 (1971)

9) W. Grosch \& J. M. Schwartz: Lipids 6, 351 (1971)

10) T. Galliard \& D. R. Phillips: Biochim. Biophys. Acta 431, 278 (1976)

要 約

オレイン酸ナトリウム液郕のキュウリ果実中で の残留分析

藤井正信, 徳村 彰, 堤 敏彦 塚谷博昭, 加納幹生, 田中 晃

アブラムシ防除剂として開発中のオレイン酸ナトリウ ム液剂（主成分としてシス-9-オクタデセン酸ナトリウ 厶を $20 \%$ 含む) のキュウリ散布後のシス-9-オクタデ セン酸 (ODA) の残留量を調べるため, ガスクロマト グラフによる分析を行なった。 二品種のキュウリ中の内 因性 ODA 量は，それぞれ $0.33 ， 0.37 \mathrm{ppm}$ であった. 二品種のキュウリ中の ODA 残留量は, 最終散布後 1 日 目はそれぞれ $1.81 ， 3.57 \mathrm{ppm}$ であり，3 日目において は，それぞれ 0.88, $1.01 \mathrm{ppm}$ へと減少した.末処理の キュウリに ODA $2.5 \mathrm{ppm}$ 添加し回収率試験を行な ったところ，回収率は 102.0～108.4\% の範囲にあっ た。 